\title{
PENGARUH PEMBERIAN Beauveria bassiana Vuill TERHADAP KEMATIAN DAN PERKEMBANGAN LARVA Spodoptera litura Fabricus DI RUMAH KACA
}

\author{
Raden M. Saleh, Rosdah Thalib dan Suprapti ${ }^{1}$
}

\begin{abstract}
The effects of beauveria bassiana vuill apllication upon the mortality and development of spodoptera litura fabricus larvae in glasshouse. A research has been done in order to know the effects of Beauveria bassiana Vuill application on the Spodoptera litura Fabricus larvae. The research was conducted in glasshouse of Jurusan Hama dan Penyakit Tumbuhan, Fakultas Pertanian Universitas Sriwijaya, by using completed randomized design with four Beauveria concentration as treatment and six replications. The treatments were $0,10^{4}, 10^{6}$ an $\mathrm{d} 10^{8}$ Beauveria spores per cc of water. Each replication consists of four units of plant sample.

The result of the study shows that $10^{8}$ spores of Beauveria caused $70 \%$ larval mortality, the highest among all concentrations. The growth of the larval weight was decreeasing following the increasing of the Beauveria concentration. The changing in the body color and reducing in eating activities were showed by the larvae as the effects of Baeuveria apllication.
\end{abstract}

Kata kunci: Beauveria bassiana, kematian larva, Spodoptera litura

\section{PENDAHULUAN}

Sampai saat ini produksi kedelai di Indonesia, ditinjau dari segi kuantitas maupun kualitas, masih tergolong rendah dibandingkan dengan negara-negara penghasil kedelai lainnya. Akibatnya, guna memenuhi kebutuhan, baik untuk bahan makanan manusia, makanan ternak atau bahan baku industri di Indonesia masih diperlukan impor kedelai. Banyak faktor yang menyebabkan rendahnya hasil kedelai di Indonesia. Salah satu di antaranya adalah adanya gangguan hama tanaman, yang merupakan salah satu faktor pembatas utamanya.

Terdapat lebih dari 20 jenis serangga hama yang dapat mengganggu tanaman kedelai (Soekarna dan Harnoto, 1985). Salah satu di antaranya adalah pemakan daun, Spodoptera litura Fabricus (Lapidoptera: Noctuidae). Kehilangan daun kedelai pada stadia vegetatif dapat digantikan oleh munculnya daun-daun baru, tetapi kehilangan daun pada stadia pertumbuhan reproduktif tidak diikuti oleh pergantian daun baru, sehingga pertumbuhan reproduktif tanaman terganggu dan pada akhirnya akan mempengaruhi produksi tanaman.

Pengendalian secara hayati untuk mengatasi gangguan S. litura, yaitu dengan pemanfaatan musuh alaminya seperti predator, parasitoid dan patogen, merupakan cara pengendalian dengan beberapa keuntungan dibandingkan cara-cara lainnya. Jamur $B$. bassiana adalah salah satu di antara musuh-musuh alami yang potensial untuk dikembangkan dalam pengendalian S. litura. Jamur ini telah diteliti oleh Pascalet pada tahun 1939 di Kamerun untuk pengendalian hama Hypothenemus hampei (Ferr.). Jamur ini dapat menginfeksi serangga yang tergolong dalam ordo Coleoptera dan Lepidoptera (Steinhaus, 1973).

Pemanfaatan jamur B. bassiana untuk pengendalian $S$. litura belum banyak dilakukan dan umumnya masih dalam tahap pengembangan. Dengan demikian masih perlu diadakan penelitianpenelitian yang mengarah kepada aplikasi jamur tersebut untuk pengendalian serangga hama S. litura. Penelitian yang dilakukan ini bertujuan untuk mengetahui pengaruh konsentrasi jamur $B$. bassiana terhadap larva $S$. litura, yang diukur dengan mortalitas, perubahan berat dan sifat larva.

\section{BAHAN DAN METODE}

Penelitian dilakukan di rumah kaca pada Jurusan Hama dan Penyakit Tumbuhan Fakultas Pertanian Universitas Sriwijaya. Penelitian menggunakan rancangan acak lengkap yang terdiri

\footnotetext{
${ }^{1}$ Dosen Jurusan Hama dan Penyakit Tumbuhan, Fakultas Pertanian Universitas Sriwijaya Palembang
} 
atas empat konsentrasi jamur B. bassiana termasuk kontrol, sebagai perlakuan, dengan enam ulangan. Setiap ulangan terdiri atas empat unit tanaman contoh. Perlakuan-perlakuan tersebut adalah konsentrasikonsentrasi jamur sebesar $10^{8}, 10^{6}$ dan $10^{4} \mathrm{spora} / \mathrm{ml}$ air serta kontrol yang menggunakan aquades.

Tanah untuk media tanaman disiapkan dengan dicampur pupuk kandang dengan perbandingan 4:1, lalu disterilkan memakai formalin $4 \%$, sebanyak $4 \mathrm{ml}$ untuk setiap $1 \mathrm{~kg}$ campuran tanah. Setelah diinkubasikan selama satu minggu, tanah yang telah disterilkan tadi dimasukkan ke dalam polybag, masing-masing sebanyak $5 \mathrm{~kg}$. Pupuk NPK diberikan sehari sebelum benih ditanam. Satu benih yang tuimbuh dari setiap polybag dipelihara sampai mencapai fase V5, pada saat dimana dilakukan peletakan larva $S$. litura instar ketiga pada cabang ketiga dari atas.

Serangga S. litura untuk penelitian ini berasal dari lapangan, yang dipelihara dan diperbanyak di rumah kaca dengan menggunakan stoples berukuran besar dan diberi makan daun kedelai varietas Wilis, yaitu varietas yang sama dengan yang digunakan pada penelitian. Ketika akan memasuki prapupa, ke dalam stoples dimasukkan tanah setebal $3 \mathrm{~cm}$ sebagai media untuk berpupa. Pupa yang diperoleh dipelihara sampai menjadi imago. Imago jantan dan betina dipasangkan dan telur-telur yang dihasilkan dari pasangan ini dipelihara dalam stoples tersendiri. Larva yang keluar dipelihara sampai menjadi imago kembali, dan seterusnya seperti prosedur sebelumnya sampai F3, pada saat mana telah diperoleh jumlah larva yang cukup unuk perlakuan. Larva-larva yang dihasilkan ini dipelihara sampai premolt instar ketiga, lalu diletakkan pada tanaman sebanyak lima ekor larva per tanaman.

Jamur B. bassiana diperoleh dari biakan murni yang tersedia di Unit Laboratorium Lapangan, Dinas Perkebunan Tingkat I Sumatera Selatan. Jamur ini diperbanyak lagi pada media PDA. Biakan digunakan setelah berumur 21 hari. Suspensi awal dibuat dengan melarutkan biakan murni jamur dengan aquades. Dari suspensi awal ini dihitung spora sebanyak $10^{8}$ per $\mathrm{ml}$ air. Selanjutnya dilakukan pengenceran bertahap, sehingga diperoleh suspensi dengan konsentrasi jamur sebesar $10^{6}$ dan $10^{4}$ per ml air. Penyemprotan suspensi jamur pada tanaman dilakukan, sesuai perlakuan, pada pada saat yang sama dengan peletakan larva.. Setelah disemprot, tanaman ditutup dengan sungkup.

Pengamatan mortalitas larva mulai dilakukan satu hari setelah penyemprotan sampai larva menjadi pupa. Persentase kematian larva dihitung dari hasil pengamatan terakhir, yaitu bilamana lebih dari separuh dari larva yang hidup telah menjadi pupa, dengan cara membandingkan jumlah larva yang mati terhadap jumlah larva seluruhnya. Selanjutnya, pertambahan berat larva dihitung dari selisih antara berat larva pada saat premolt instar keempat dengan beratnya pada saat premolt instar ketiga. Terhadap larva yang mati dilakukan pembedahan dan diamati saluran pencernaannya. Bagian dari tumbuh larva ini juga ditempatkan pada media PDA untuk dilihat sampai munculnya spora. Pengamatan prilaku larva dilakukan dengan melihat gerakan dan aktivitas larva termasuk morfologi tubuh larva. Kemampuan merusak larva juga diamati untuk melihat kemampuan makannya, yang dinilai dengan menggunakan rumus persentase serangan larva yang dimodifikasi dari Kremer dan Unterstanhoper (1967).

\section{HASIL DAN PEMBAHASAN}

Hasil pengamatan terhadap mortlaitas larva memperlihatkan bahwa larva-larva mulai mati lima hari setelah aplikasi suspensi jamur. Mortalitas larva tertinggi adalah pada konsentrasi jamur $10^{8} \mathrm{spora} / \mathrm{ml}$ air, yang kemudian secara berurutan oleh konsentrasikonsentrasi yang lebih rendah (lihat Tabel 1). Dengan demikiam, semakin tinggi konsentrasi jamur $B$. bassiana menyebabkan makin tinggi pula mortaliotas larva, sehingga belum dapat ditemukan konsentrasi optimumnya. Hal ini diduga kemungkinan berhubungan dengan jumlah konidia, pada masingmasing perlakuan, yang berkecambah membentuk hifa dan mengadakan penetrasi melalui kulit yang peka sebelum berkembang dalam tubuh larva dan menyebabkan kematian larva. Ferron (1981) menyatakan bahwa jumlah konidia sangat mempengaruhi perkembangan jamur. Jumlah konidia yang banyak akan menyebabkan perkembangan jamur makin cepat dan daya infeksinya makin besar. 
Tabel 1. Mortalitas, pertambahan berat dan intensitas serangan larva S. litura pada tanaman yang disemprot dengan suspensi jamur B. bassiana

\begin{tabular}{cccc}
\hline $\begin{array}{l}\text { Konsentrasi Jamur } \\
\text { (spora/ml air) }\end{array}$ & $\begin{array}{l}\text { Mortalitas Larva } \\
(\%, 12 \mathrm{hsp})\end{array}$ & Pertambahan berat larva (mg) & \begin{tabular}{l} 
Intensitas serangan $_{(\%)^{*}}$ \\
\hline 0
\end{tabular} \\
\hline $0^{4}$ & $0,0 \mathrm{a}$ & $92,83 \mathrm{a}$ & $63,78 \mathrm{a}$ \\
$10^{6}$ & $38,3 \mathrm{~b}$ & $32,17 \mathrm{a}$ & $40,92 \mathrm{~b}$ \\
$10^{8}$ & $62,5 \mathrm{c}$ & $25,25 \mathrm{~b}$ & $37,95 \mathrm{~b}$ \\
\hline
\end{tabular}

*) Angka-angka yang diikuti dengan huruf yang sama pada kolom yang sama berarti berbeda tidak nyata pada taraf uji 5\% menurut uji jarak Duncan, bila ditransformasi arcsin $\sqrt{ } \%$; hsp = hari setelah perlakuan.

**) Angka-angka yang dikuti dengan huruf yang sama berarti berbeda tidak nyata pada taraf uji 5\% menurut uji jarak Duncan

Data pengamatan pertambahan berat larva diketahui bahwa semakin tinggi konsentrasi suspensi jamur yang diberikan semakin rendah pertambahan berat larva (Tabel 1). Diduga bahwa hal ini berkaitan dengan aktivitas makan yang terganggu dari larva. Patogen yang disemprotkan pada tanaman, disamping dapat memasuki larva melalui kulit larva yang peka, juga langsung dikonsumsi larva melalui daun yang dimakannya. Dengan demikian makin tinggi konsentrasi suispensi jamur pada daun semakin banyak pula patogen tersebut yang masuk ke saluran pencernaan makanan larva. Perlakuan dengan suspensi yang pekat mengandung konidia yang lebih nanyak serta perkembangan jamur di dalam tubuh larva akan lebih cepat dan emnyebabkan aktivitas makan larva terganggu.

Dugaan terjadinya hal tersebut di atas dapat diketahui dari hasil pembedahan terhadap larva yang mati, yang memperlihatkan isi saluran percernaan larva yang kering dan berwarna hitam. Kulit larva bagian dalam berwarna merah dengan warna putih di sekitarnya. Gejala-gejala ini adalah gejala yang ditunjukkan oleh zat pengurai khitin yang dikenal dengan nama Beauvericin, sebagai racun yamng dihasilkan oleh konidia jamur tersebut. Hasil pengamatan di bawah mikroskop juga membuktikan adanya konidia jamur $B$. bassiana dari hasil penanaman larva yang mati di media PDA.

Berkurangnya aktivitas makan dan kemampuan megkonsumsi makanan dari larva-larva pada tanaman yang disemprot dengan konsentrasi jamur yang lebih tinggi juga dapat dilihat dari besarnya kerusakan tanaman. Intensitas serangan larva pada tanaman yang disemprot dengan suspensi jamur yang lebih tinggi adalah lebih rendah. Hal ini juga dapat dilihat pada Tabel 1 . Terjadi beberapa perubahan pada prilaku dan kondisi larva S. litura sebagai akibat pemberian $B$. bassiana, disamping adanya pengaruh pada aktivitas gerak larva. Secara umum prilaku dan kondisi larva pada masing-masing konsentrasi suspensi jamur adalah sebagaimana terlihat pada Tabel 2.

Penyemprotan suspensi jamur pada tanaman kedelai tidak mempengaruhi pertumbuhan tanaman. Hasil pengamatan untuk melihat pengaruh dari keberadaan jamur $B$. bassiana pada tanaman menunjukkan tidak adanya perubahan atau penyimpangan pada morfologi dan pertumbuhan tanaman. Perubahan yang terlihat pada tanaman hanyalah kerusakan daun sebagai akibat dikonsumsi oleh larva S. litura. 
Tabel 2. Prilaku dan kondisi larva S. litura akibat pengaruh pemberian suspensi jamur B. bassiana

Konsentrasi jamur Perilaku dan kondisi larva (spora/ml air)

$0 \quad$ Aktivitas gerak larva biasa dan nafsu makannya kuat. Warna permukaan tubuh larva cerah dan tidak kusam. Morfologi tubuh larva normal

$10^{4} \quad$ Aktivitas gerakan larva terlihat sedikit lamban dan nafsu makannya juga sedikti berkurang. Warna permukaan tubuh tidak terlalu kusam, sedangkan bentuk tubuh larva sedikit gemuk

$10^{6} \quad$ Aktivitas gerak larva sudah terlihat lebih lamban dan nafsu makannya juga sudah berkurang. Warna permukaan tubuh larva sedikit kusam dan bentuk tubuhnya juga sedikit mengecil

$10^{8} \quad$ Aktivitas gerak larva sudah sangat lamban dan nafsu makannya juga sangat berkurang. Warna tubuh larva tampak kusam dan pucat, sedangkan bentuk tubuh larva sangat mengecil dan kurus

\section{KESIMPULAN DAN SARAN}

Dari hasil penelitian yang telah dilakukan dapat disimpulkan bahwa pemberian suspensi jamur $B$. bassiana pada tanaman kedelai dapat menyebabkan kematian larva $S$. litura. Jamur $B$. bassiana mempengaruhi larva melalui penetrasi jamur pada kulit larva maupun melalui daun yang dikonsumsi larva. Pertambahan berat larva akan semakin rendah dengan semakin tingginya konsentrasi suspensi jamur yang diberikan, disamping adanya beberapa perubahan pada morfologi dan prilaku larva. Pemberian suspensi jamur $B$. bassiana tidak mempengaruhi pertumbuhan tanaman.

Disarankan untuk diadakan penelitian lebih lanjut tetntang umur jamur $B$. bassiana yang efektif dalam mempengaruhi larva S. litura.

\section{DAFTAR PUSTAKA}

Ferron, P. 1981. Pest control by the fungi Beauveria and Metarhizium. In H. D. Burges (ed.): Microbial Control Pests and Plant Diseases 1970-1980. Academic Press, London.

Kremer, F. W. \& G. Unterstanhoper. 1967. Computation of the results of crop protection experiments by method of Towsend and Herberger. Pflanzenschuts Nachrichten Bayer 20(4):625-628.

Soekarna, D. \& Harnoto. 1985. Pengendalian hama kedelai. Dalam Kedelai. BadanPenelitian dan Pengembangan Tanaman Pangan, Bogor.

Steinhaus, A E. 1973. Microbial diseases of insects. In P. De Bach (ed.): Biological Control of Insect Pests and Weeds. John Wiley and Sons, New York. 